beds can be traced through Hope on to Hathersege; and along the brook side, below Mam Tor, a good section is displayed, where they are seen abutting against the lower limestones, Along the stream at Hope good sections are also exposed, and they are seen in several places on the road to Bradwell. The bottam beds of the shales are intercalated with stony bands composed of the remnants of encrinite-stems and fragments of shells, and have been calised by the denudation of the limestone during their formation. The bottom shales are rich in Aviculo-pectens, Goniatites, Posidonia, etc., and the numerous iron-stone bands higher up the hill are rich in small goniatites, which are frequently found pyritized.

The most striking peculiarity of these shales is the fact that about a couple of miles from Castleton, where they rest upon the limestone, the bitumen which has steeped them has also percolated and oozed out into the limestone, turning it quite black, as also the fossils which, when split; open, are often seen to contain a little globule of bitumen. Here wo see the decomposed remains of two subdivisions separated by a great gulf of time, mingling together, both testifying to the great law of death which has prevailed since the dawn of life. When the fossils of the limestone are cleft open, they are often seen to contain a little globule of bitumen. Do not all the labours of the geologist prove that death is as much a natural law as that of birth, and that creation has been concomitant with extinction, as with individuals has been life and death?

\title{
NOTES ON A NEW MASS OF METEORIC IRON FROM THE CORDILLERA OF COPIAPO, CHILE.
}

By Wm. Boldaert, F,R.G.S.,

Cor. Mem. Univ. Chile and Amer. Ethnological Society, eto.

This was found by a muleteer, in June, 1858, when passing the Cordillera from Catamarea to Copiapo, and brought by him to the latter city. IIe took it to be a rodado, or piece of silver-ore that had been broken from a vein and rounded by being washed with stones, say in the bed of a river; but on its being examined by Dr. David Gareia (a pupil of Domeyko), at Copiapo, he pronounced it to be a mass of meteoric iron,

Dr. D. Garcia is the manager of the " Transito" maquina or silver amalgamating works, and has this specimen in his possession. Mr. Abbott tells me it is considered a most interesting specimen, being so perfect (nota broken fragment), and whole. ToL. v.

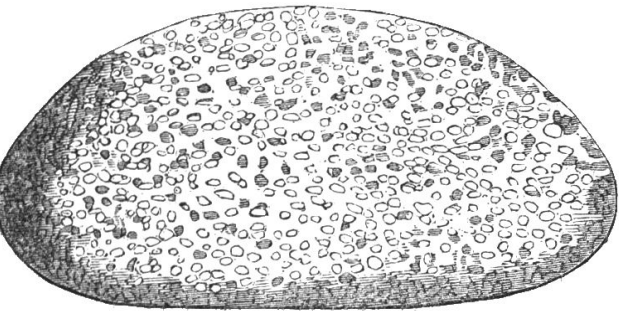

Meteorite from Copiapo. 
The mass is covered thickly with a series of shallow pits or depressions, about $\frac{1}{8}$ to $\frac{1}{10}$ of an inch deep. The spaces between the holes are bright like steel. Its weight is about 12 or 13 lbs.

In consequence of finding a difficulty in fixing the position or positions of the Atacama Meteorite in 1826, I gave Peine, Guanaquero, Chala, and two other spots north of Challa, all in the desert of Atacama; also Miño, to the east of Mani, near the Peruviau and Bolivian boundaries. I tried to get across the desert in 1828, from the coast of the Pacific, in the hape of examining the localities of Guanaquero and Peine, near to one or other of which places I hoped to find the meteoric deposit. I was lost for awhile in the desert of Atacama, and had to return to the coast. Near to Toconao, nortb-east of Peine, was supposed by Sir W. Parish to be the spot; but in 1853, Dr. Philippi determined Imilac, a few miles south-west of Peine, to be the spot, or one of the spots of the fall of the Atacama Meteorite.

A very large specimen from Atacama is in the possession of Domeyko, in Santiago, in Chile; some others I have seen, as well as many small fragments which fell at Imilac; as to my small specimen obtained in 1826, when $I$ was in Tarapuca, it may or may not have been collected at Imilac.*

The large specimen of the Atacama Meteorite deposited by me in the British Museum, I procured on the west coast in 1854. I have had some doubts as to whether Imi]ac ought to be given as the locality of its fall. I made this observation in my paper to the Meteorological Society, 1858, as to this specimen; the same will apply to a slice of meteoric stone in the same IMuseum, and that in the Museum of Practical Geology. The information I had was what I let the British Museum have, that it (and others, one weighing over 50lbs.) were brought to Cobija by a muleteer, from "somewhere to the east in the desert of Atacama, and it was thought there were several similar deposits in the track to Antofogasta."

These specimens hare the external mechanical character of the Imilac specimens, but the metallic part is dark, as if much oxidized, and the earthy part is more crystalline.

Nicol, in his 'Mineralogy,' gives an analysis by Rivero of meteoric iron from "Potosi :"-iron, 90.24; nickel, $976=100 \cdot 0$. Domeyko gives for the Atacama one (Imilac) :-iron, 8454 ; nickel, 8.24 ; cobalt, 1.14; silica, 0.16 . From this difference of composition compared with that of the one from "Potosi," we may say that Imilac was not its place of deposit,

I adrert in my paper to the Meteorological Society to three stones found four leagues inland from Playabrava $\left(23^{\circ} 35^{\prime}\right)$, two round and porous, the other porous, flat, and triangular. I suspect them to be meteoric (for they are said to be of "iron"), and the locality they were found in, although near the latitude of Imilac, is much further to the west. Having disposed of these amygdalo-peridotic varieties,

* I gave $23^{\circ} 30^{\prime} \mathrm{S} ., 68^{\circ} 50^{\prime} \mathrm{W}$. as the position of Dr. Reid's specimens (which are at Ratisbon), and there may be a doubt that they came from Imilac, which is in $23^{\circ} 49^{\prime} \mathrm{S}$., $69^{\circ} 14^{\prime} \mathrm{W}$. 
that of Imilac, which may have fallen about 1820 , I will now refer to Shepard's account in 1850 of three new North American meteorites, with observations upon the general distribution of such bodies, and on the falling of meteorites over a limited zone or area of the earth's surface. He says :- " Out of the fourteen depositions of meteoric matter on the American continent within the last few years, thirteen have taken place between $33^{\circ}$ and $44^{\circ} \mathrm{N}$; ; one only at Maceio, in Brazil, south of the Equator,-a distribution exceedingly unequal." He however concludes "that there is a zone or region over which meteoric falls are more frequent than elsewhere."

Run the eye easterly from the meteoric region of A tacama, on the west coast of South America, for ten degrees of longitude, and now we come upon that extraordinary deposit of solid meteoric iron of Otumpa* (about thirteen tons), of which there is so magnificent a specimen in the British Museum. Near Bahia, in Brazil, is another mass of iron of $14,000 \mathrm{lbs}$.

On Arrowsmith's old map of South A merica, at a distance of twentythree geographical miles S.S.W. of the city of Tucuman, appears the word "Meteores;" does this mean that meteoric iron has been found there? Antofogasta is about $2^{\circ}$ W.N.W. of the "Meteores," and $I$ have reason to believe that meteoric iron exists about there.

In the map to Wilcocke's 'Buenos Ayres,' at the junction of the Bermejo and Paraguay rivers are the "Montes de Hierro;" monte may mean mountain or forest. This locality is about $2^{\circ} \mathrm{N}$.E. of Otumpa, and the iron spoken of here may be meteoric.

In the 'Coleccion de Memorias Cientificas, etc., por M. E.de Rivero $y$ Ustariz' (Brussels, 1857), there are details and analyses of several masses of meteoric iron found in the Cordillera of the Andes (of Bogotá).

My impression is, that when this subject of meteoric zones is worked out, more falls will have to be recorded in South America than given by Shepard.

\section{PROCEEDINGS OF GEOLOGICAL SOCIETIES.}

Geological Society of London:-January 22, 1862.-Sir R. I. Murchison, V.P.G.S., in the chair. The following communications were read:-

1. "On some Flint Arrow-heads (8) from near Baggy Point, North Devon." By N. Whitley, Esq., communicated by J. S. Enys, Fsq., F.G.S. Immediately beneath the surface-soil above the "raised beaches" of North Devon and Cornwall, the author has observed broken flints; and even

* It is not known when the Otumpa iron fell. It was visited by Celis and Cerviño in 1783. The length of it is $3 \frac{1}{4}$ yards, 2 yards in width, 4 feet 6 inches deep, and contains $9 \frac{3}{4}$ cubic yards. This appears to be independent of smaller pieces. It is called by the natives the Masa de fierro, or mass of iron; the meteorite of the Chaco; of the Chaco Gualamba. It was discovered by people from Santiago del Estero on one of their expeditions to "malear," or hunt for honey and wax. It is in about $27^{\circ} 43^{\prime} \mathrm{S} .2^{\circ} 40^{\prime}$ W. of Buenos Ayres. 